\title{
Temporal and regional variability of Arctic sea-ice coverage from satellite data
}

\author{
Ge PENG, ${ }^{1}$ Walter N. MEIER ${ }^{2 *}$ \\ ${ }^{1}$ North Carolina State University, Cooperative Institute for Climate and Satellites - North Carolina (CICS-NC) at \\ NOAA's National Centers for Environmental Information, Asheville, NC 28801, USA \\ E-mail: gpeng@ncsu.edu \\ ${ }^{2}$ Cryospheric Sciences Lab, NASA Goddard Space Flight Center, Greenbelt, MD 20771, USA
}

\begin{abstract}
With rapid and accelerated Arctic sea-ice loss, it is beneficial to update and baseline historical change on the regional scales from a consistent, intercalibrated, long-term time series of sea-ice data for understanding regional vulnerability and monitoring ice state for climate adaptation and risk mitigation. In this paper, monthly sea-ice extents (SIEs) derived from a passive microwave sea-ice concentration climate data record for the period of 1979-2015, are used to examine Arcticwide and regional temporal variability of sea-ice cover and their decadal trends for 15 regions of the Arctic. Three unique types of SIE annual cycles are described. Regions of vulnerability within each of three types to further warming are identified. For the Arctic as a whole, the analysis has found significant changes in both annual SIE maximum and minimum, with $-2.41 \pm 0.56 \%$ per decade and $-13.5 \pm$ $2.93 \%$ per decade change relative to the 1979-2015 climate average, respectively. On the regional scale, the calculated trends for the annual SIE maximum range from +2.48 to $-10.8 \%$ decade $^{-1}$, while the trends for the annual SIE minimum range from 0 to up to $-42 \%$ decade $^{-1}$.
\end{abstract}

KEYWORDS: climate change, ice and climate, sea ice

\section{INTRODUCTION}

Arctic sea-ice coverage, especially the summer ice coverage, has been observed to be undergoing accelerated depletion since satellite-based measurements became available in the late 1970s (e.g. Parkinson and others, 1999; Comiso and Nishio, 2008; Peng and others, 2013; Parkinson, 2014; Serreze and Stroeve, 2015). Arctic ice has been declining at a faster rate for the last 20 years (1997-2016) compared with the average decline over the previous 20 years (1978-97). The record low value for annual minimum seaice coverage level was observed in 2012, breaking records previously set in 2005, and then again in 2007. The 2016 value tied with 2007 for second lowest Arctic sea-ice minimum on record according to the National Snow and Ice Data Center (NSIDC) (http://nsidc.org/arcticseaicenews/ 2016/09/2016-ties-with-2007-for-second-lowest-arctic-seaice-minimum/). Since the late 1970s, satellite measurements have recorded a decrease of $10-15 \%$ per decade in the Arctic annual minimum sea-ice extent (SIE), as measured by the area within the $15 \%$ concentration contour (e.g. Comiso and Nishio, 2008; Cavalieri and Parkinson, 2012), with a reduction of $49 \%$ sea ice in extent based on remotesensing observations (Cavalieri and Parkinson, 2012) and $80 \%$ in sea-ice volume based on output from the PanArctic Ice Ocean Modeling and Assimilation System (PIOMAS; Zhang and Rothrock, 2003), relative to the 1979-2000 average. This loss of Arctic sea ice is also occurring at a rate that is faster than what climate models with enhanced greenhouse forcing have predicted (Stroeve and others, 2012). In addition, the sea-ice winter ice extent has been setting record lows for the last 3 years in a row

*Now at: National Snow and Ice Data Center/University of Colorado at Boulder, Boulder, CO 80309, USA.
(Thompson, 2017), reducing the amount of Arctic sea ice available for potential melting.

Temporal and regional variability of sea-ice coverage has also been observed, indicating that the changes are not uniform in space and time as a result of local geographic and weather effects (e.g. Parkinson and others, 1999; Liu and others, 2004; Meier and others, 2007; Koldunov, 2010). Sea-ice decline has been observed to be most pronounced in the coastal zones of the Laptev, East Siberian, Chukchi, Barents and Beaufort Seas (Meier and others, 2007). Arctic summer circulation may contribute to regional sea-ice anomalies (Lynch and others, 2016). Spatial sea-ice variability may lead to a large spread in climate model seaice area projections and therefore induce high uncertainty on regional scales (Semenov and others, 2015).

The rapid and accelerated sea-ice loss has local and remote effects on climate and weather systems (Bhatt and others, 2014; Vihma, 2014). It poses extreme challenges to the sustainability and resilience of the Arctic system, while potentially bringing new opportunities, such as access to new sources of natural resources and ocean transportation routes (ACIA, 2004; Kattsov and others, 2010; Jeffries and others, 2014).

Since satellite-based measurements became available in the late 1970s, satellite-derived sea-ice estimates of concentration and extent have helped the cryosphere community understand and monitor Arctic sea-ice state. However, multiple types of sensors from multiple missions are utilized to formulate long-term time series of sea ice. Therefore, it is essential to update and baseline the historical change on the Arctic-wide and regional scales from a consistent, intercalibrated, well-documented, long-term time series of seaice data to help understand the vulnerability of the Arctic system, monitor and communicate future changes, and guide future opportunity development. In this paper, a 
long-term time series of sea-ice coverage is analyzed using a satellite-based, intercalibrated, and mature sea-ice concentration data product for the period of 1979-2015. The temporal and regional variability of sea-ice coverage in the Arctic is examined and regions of summer-opening vulnerability to further warming are identified.
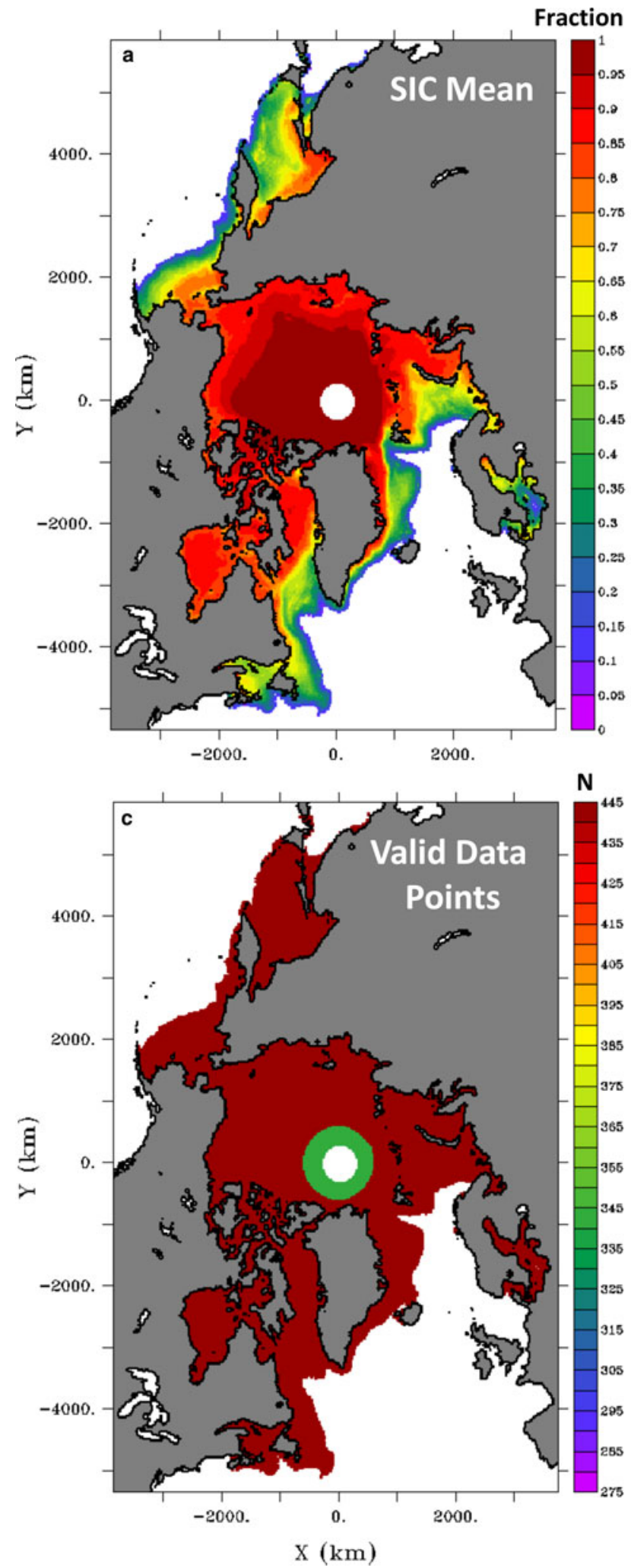

\section{DATASET DESCRIPTION}

Monthly sea-ice concentration fields from a long-term, consistent, satellite-based passive microwave sea-ice concentration climate data record (CDR) are utilized (Meier and others, 2013). This sea-ice concentration product leverages two well-established concentration algorithms - namely, the
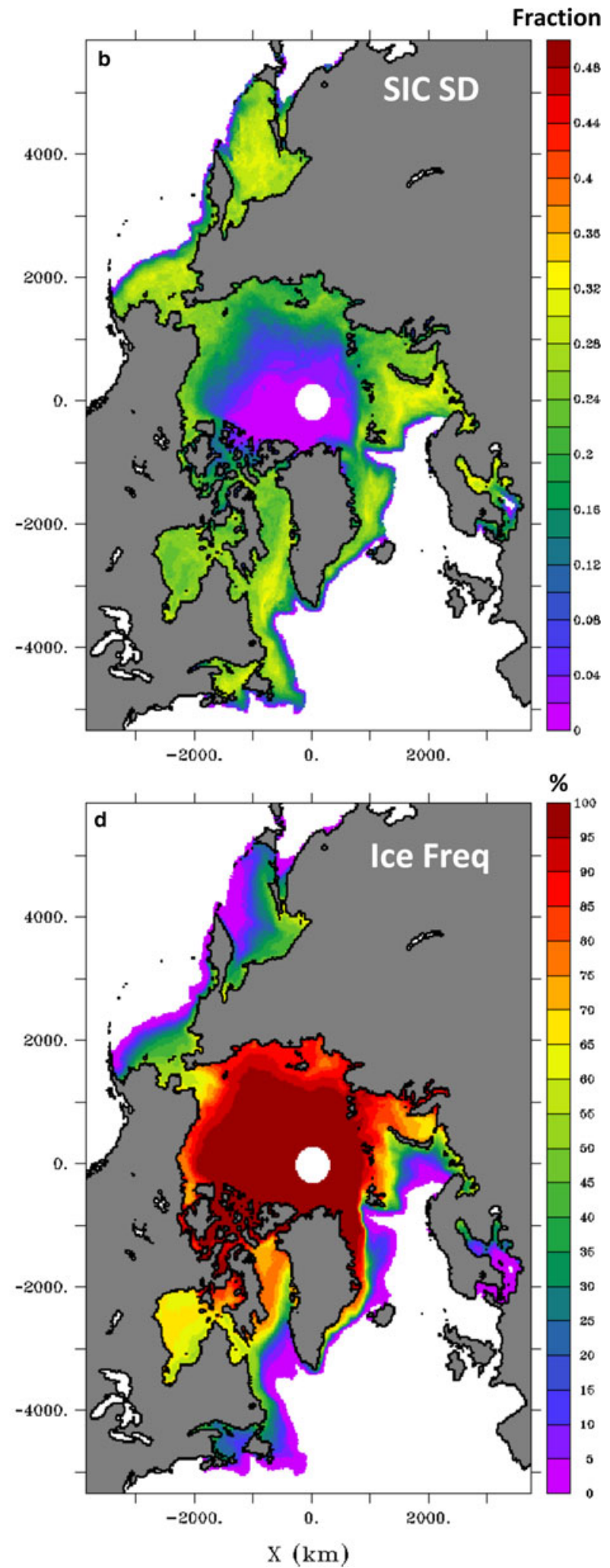

Fig. 1. Spatial distributions of (a) SIC climatological mean from monthly fields, (b) SIC SD, (c) valid data points and (d) percentage of ice presence for SIC $\geq 15 \%$, for the period of 1979-2015. The color bar unit is ice area fraction for (a) and (b). Landmasses are shaded gray. Other water masses and the pole hole are denoted in white. 
NASA Team (NT) and Bootstrap (BT) - both developed at and produced by the NASA Goddard Space Flight Center (GSFC). The CDR product is generated by a combined sea-ice algorithm and meets CDR criteria in terms of reproducibility, transparency, documentation and metadata standards. Description and verification of the CDR can be found in Peng and others (2013) and Meier and others (2014), respectively.

The monthly merged Goddard sea-ice concentration fields (hereinafter referred to as GSFC SIC) for the period of 1979-2015 are used for the study. These GSFC SIC fields are on a nominal $25 \mathrm{~km} \times 25 \mathrm{~km}$ grid in the northern polar region. Previous studies of SIE trends have been using SIC retrievals from either the NT or BT algorithm. The CDR merging algorithm helps mitigate the known issue of underestimated SIC values from NT and BT algorithms (Meier and others, 2014). It is particularly improved in the Arctic summer over the previous publications that used the NT algorithm; this means that the summer trends likely have more confidence because there is less influence of melt on the summer concentration trend. The CDR product matches closely with the BT algorithm (Meier and others, 2014), but regional trends from BT have not been published since 2008 with data through 2007 (Comiso and Nishio, 2008).

The sea-ice concentration estimates derived from satellite measurements are generally reliable for values that are at $15 \%$ or higher, with sensor footprints up to $\sim 45 \mathrm{~km} \times \sim 70 \mathrm{~km}$. The spatial resolution varies depending on the data source. The accuracy of estimated SIE and their trends is dependent on the SIC retrieval accuracy and the satellite measurement resolutions.

SIE in this paper is computed based on the $15 \%$ SIC threshold from the monthly GSFC SIC fields for the record period of 1979-2015. Retrieved estimates of zero SIE derived from this approach does not necessarily mean that the region is totally ice-free, but instead denotes the state that there are no grid cells with SIC values of higher than $15 \%$ estimates from the GSFC SIC algorithm. All the cells within the pole hole are assumed to be covered by at least $15 \%$ of ice.

Spatial distributions of climatological averages and SDs of GSFC SIC from monthly fields over 1979-2015 are shown in Figs. $1 \mathrm{a}$ and $\mathrm{b}$ with the number of valid data points in Fig. 1c. The variation in valid data points in the central Arctic is due to the change in the pole hole sizes in July 1987. Figure $1 \mathrm{~d}$ shows the percentage of ice presence with SIC $>15 \%$ (hereinafter referred to as ice frequency).

The areas with larger spatial variability appear to have larger temporal variability (comparing Fig. 1a with b) and relative low ice frequency (comparing Fig. 1a with $d$ ) as well. This is largely driven by the fact that ice is seasonal in these areas. In some regions, there are persistent winter freeze-ups or summer openings. As the result, the monthly SIC values in these areas can be mostly either zeros in summer months or ones in winter months. Therefore, the distribution of SIC (over the 12 calendar months) may not be normal. Although the standard derivation shown in Fig. 1b still measures the deviance of the monthly SIC values from their climatology averages shown in Fig. 1a, it is possible all the values of SIC may not necessarily lie within three SDs. Furthermore, depending on whether the distribution skews toward zero or one, the mean, namely, the climatology average, is smaller or larger than its median.
The regional definitions from Meier and others (2007) are adapted here, except the seas of Japan and Okhotsk are now separated (see Fig. 2). Monthly sea-ice coverage (area and extent) are computed for the whole Arctic and each of the 15 regional divisions, but only the results of SIE are discussed below.

\section{TEMPORAL AND SPATIAL VARIABILITY OF SEA-ICE COVERAGE}

\section{Seasonal and annual cycle variability of SIEs}

After Yashayaev and Zveryaev (2001), the seasonal cycle has been considered to be the evolution of SIE through the year and the annual cycle the annual harmonic. As expected, the Arctic region as a whole shows a distinct seasonal cycle, with the annual maximum of SIE in March and minimum in September (Fig. 3a). The interannual range and variability for the annual minimum are much larger than that for the annual maximum (see the spread in Fig. 3a and compare the SD values of annual SIE minimum and annual maximum in Table 1). However, the pattern varies in the individual regions. For example, more than one-third of the regions display larger SD values for the annual SIE maximum (Fig. 3; see also Table 1), while half of them show very little to no annual maximum spread but a larger annual minimum spread (Fig. 3; see also Table 1). These very small annual maximum/minimum spreads are due to nearly complete ice freezing/melting in winter/ summer, respectively (see the categories of seasonal cycle characteristics below). The Barents Sea SIE climatological average reaches its annual maximum in April, with annual SIE maximum time ranging from February to May (Fig. 3d). An annual SIE maximum at the Bering Sea occurred in April at least once (Fig. 3g), while the Sea of Japan tends to reach its SIC annual maximum in February (Fig. 3e).

Generally speaking, the characteristics of seasonal evolution of monthly means and their spreads can be categorized as the following three types.

a) Type I - Distinct annual cycle with sinusoidal temporal evolution (Figs 3a-d: Arctic, Baffin/Newfoundland Bay, Greenland Sea and Barents Sea); these geographic

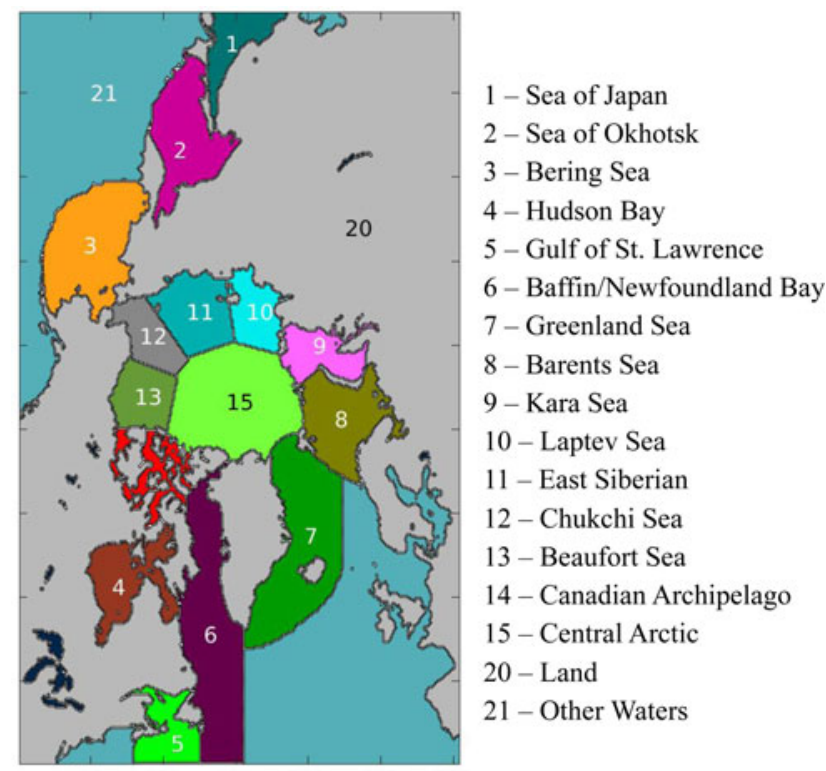

Fig. 2. Location map of the regions in Arctic. 

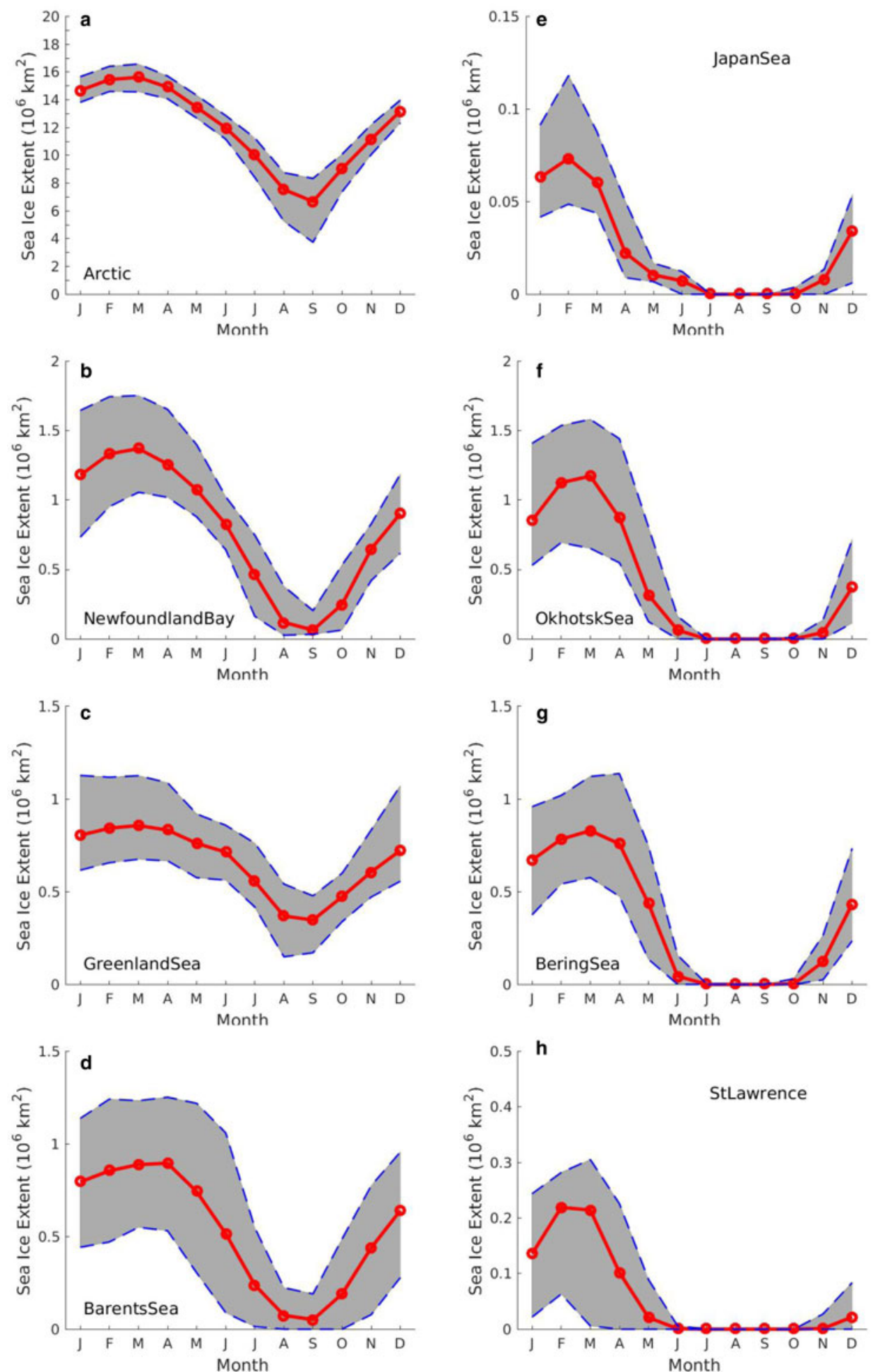

Fig. 3. Type I (left panels) and type II (right panels) seasonal cycles of climatological average of monthly SIE $\left(10^{6} \mathrm{~km}^{2}\right.$, thick red line with filled circles) and the maximum and minimum values for each month (dashed blue lines) for the regions of (a) Arctic, (b) Newfoundland Bay, (c) Greenland Sea, (d) Barents Sea, (e) Japan Sea, (f) Okhotsk Sea, (g) Bering Sea and (h) Gulf of St. Lawrence. SIE is computed assuming that all the cells within the pole hole are covered by at least $15 \%$ of ice. Shading area represents the spread of monthly SIE values for the period of 1979-2015.

regions are not bound by land on all sides, yet retain some ice year-round, allowing a fully sinusoidal seasonal cycle to exist. The Arctic as a whole has a large spread for the summer SIE minimum, while the other three regions display relatively large spreads for the winter SIE maximum. The summer-opening vulnerability can be seen at the Newfoundland Bay and Barents Sea, with at or near zero SIE values. However, all type I regions could potentially lose more ice during summer and eventually could become open in the summer.

b) Type II - Complete summer opening (Figs 3e-h: Japan Sea, Okhotsk Sea, Bering Sea and Gulf of St. Lawrence). This type exhibits a distinct late fall and winter rebuild and a spring and early summer melt with 
Table 1. Basic statistical attributes of sea-ice extent $\left(\mathrm{SIE}, 10^{6} \mathrm{~km}^{2}\right)$, decadal trends $\left(10^{6} \mathrm{~km}^{2}\right.$ decade $\left.{ }^{-1}\right)$ and their margin of error* $\left(10^{6} \mathrm{~km}{ }^{2}\right.$ decade $^{-1}$ ) at the $95 \%$ confidence level

\begin{tabular}{|c|c|c|c|c|c|c|c|c|}
\hline \multirow[t]{2}{*}{ Region ID } & \multicolumn{4}{|c|}{ Annual SIE maximum $\left(10^{6} \mathrm{~km}^{2}\right)$} & \multicolumn{4}{|c|}{ Annual SIE minimum $\left(10^{6} \mathrm{~km}^{2}\right)$} \\
\hline & Mean & SD & Trend & Margin of error & Mean & SD & Trend & Margin of error \\
\hline Arctic & 15.63 & 0.49 & -0.38 & 0.087 & 6.68 & 1.15 & -0.9 & 0.2 \\
\hline Japan Sea & 0.074 & 0.015 & -0.0053 & 0.0042 & 0 & 0 & 0 & 0 \\
\hline Okhotsk Sea & 1.19 & 0.19 & -0.093 & 0.051 & 0 & 0 & 0 & 0 \\
\hline Bering Sea & 0.86 & 0.12 & 0.021 & 0.038 & 0 & 0 & 0 & 0 \\
\hline Hudson Bay & 1.19 & 0 & 0 & 0 & 0.037 & 0.033 & -0.0085 & 0.01 \\
\hline Gulf of St. Lawrence & 0.23 & 0.053 & -0.023 & 0.019 & 0 & 0 & 0 & 0 \\
\hline Newfoundland Bay & 1.39 & 0.18 & -0.060 & 0.053 & 0.063 & 0.033 & -0.0084 & 0.010 \\
\hline Greenland Sea & 0.89 & 0.13 & -0.09 & 0.028 & 0.34 & 0.089 & -0.033 & 0.026 \\
\hline Barents Sea & 0.94 & 0.15 & -0.10 & 0.034 & 0.049 & 0.057 & -0.016 & 0.017 \\
\hline Kara Sea & 0.93 & 0.0004 & -0.000093 & 0.00013 & 0.24 & 0.19 & -0.1 & 0.048 \\
\hline Laptev Sea & 0.89 & 0 & -0 & 0 & 0.43 & 0.21 & -0.131 & 0.049 \\
\hline East Siberian & 1.32 & 0.00022 & -0.00011 & 0.00006 & 0.82 & 0.34 & -0.22 & 0.077 \\
\hline Chukchi Sea & 0.84 & 0 & 0 & 0 & 0.32 & 0.17 & -0.12 & 0.034 \\
\hline Beaufort Sea & 0.94 & 0 & 0 & 0 & 0.65 & 0.17 & -0.098 & 0.042 \\
\hline Canadian Archipelago & 0.75 & 0 & 0 & 0 & 0.54 & 0.13 & -0.09 & 0.029 \\
\hline Central Arctic & 3.22 & 0 & 0 & 0 & 3.13 & 0.10 & -0.051 & 0.028 \\
\hline
\end{tabular}

The trends in bold are significant at the $95 \%$ confidence level using Student's $t$ test.

* The margin of error for the linear trend at the 95\% confidence level is computed as: 2.028 StdErr, where StdErr denotes the standard error of the linear regression slope.

a complete and persistent summer opening. The mean, minimum and maximum of monthly SIE values are all at the zero SIE, and this pattern persists for more than 2 months in summer. Note that zero SIE value represents a state such that there is no cell that has a SIC value of more than $15 \%$ in the region. These regions are vulnerable to further warming because there is no multi-year ice to keep the region cool and to reflect solar radiation, allowing more solar insolation that would lead to earlier melt and later freeze-up, expanding the open season (e.g. Polyakov and others, 2012).

c) Type III - Complete or near-complete winter freeze-up (Fig. 4: the rest of the eight regions, i.e. Hudson Bay, Laptev Sea, East Siberian, Chukchi Sea, Beaufort Sea, Canadian Archipelago, Kara Sea and Central Arctic). This type shows the rapid late fall and early winter freeze-up for the whole region with early summer melting. The mean and minimum of monthly SIE values are very close to that of the monthly SIE maximum and this pattern persists for more than 2 months in winter. The annual SIC minimums for Hudson Bay, Laptev Sea, East Siberian, Chukchi Sea and Kara Sea have reached zero at least once (Figs $4 \mathrm{a}-\mathrm{d}$ and g). They are the most vulnerable regions in this group to further warming to become routinely opening during summer, although the potential risk exists for all Arctic regions.

The Kara Sea and Central Arctic regions are noticeable for not always being completely frozen for the whole region every winter (Figs $4 \mathrm{~g}$ and $\mathrm{h}$ ); the inflow of warmer Atlantic water can in some years keeps small areas of these regions ice-free through the winter (e.g. Polyakov and others, 2017). We will refer to them as type IIla.

\section{Temporal distributions of SIEs}

Figure 5a shows the temporal distribution of monthly SIE over the whole Arctic. Although, as expected, there is a dominant annual SIE cycle, the interannual variability is noticeable with overall decreasing values in both annual SIE maximums and minimums. One region from each of three aforementioned seasonal cycle types has been selected to demonstrate the different seasonal variability characteristics at the regional scale (Figs 5b-d). In some regions, such as the Greenland Sea (Fig. 5b), year-round variability is seen with distinct and pronounced annual minimums. Other regions, such as the Bering Sea (Fig. 5c), have ice-free conditions every summer and SIE variability is primarily limited to winter; in addition, contrary to most other regions, the Bering Sea shows relatively higher winter (e.g. March) SIE in recent years (2007-15). This positive trend of the annual maximum SIE in the Bering Sea has been noted by Cavalieri and Parkinson (2012) with 1979-2010 sea-ice data. It is also worth noting the lower than the normal seaice coverage in the last two winters (2016/17). Although it may not reverse the long-term trend, it warrants close, continual monitoring for the region.

Finally, other regions, such as the Chukchi Sea, are fully covered by ice in winter and thus have no variability during this period, but rather have increasingly enhanced summer opening (Fig. 5d). These different temporal variability characteristics on the regional scales clearly demonstrate the need for regional monitoring in addition to that of the whole Arctic. Interannual variability in sea-ice summeropening beginning and ending dates can also be observed on the regional scale, though visually, clear trends are not discernible (Figs 5a-d). A study is underway to examine and baseline the long-term average and variability of seaice retreat and advance dates in these regions.

\section{Decadal trends of SIEs}

Time series of the annual SIE maximum, minimum and the spread along with decadal trends for the Arctic and selected regions are shown in Fig. 6. For the Arctic region as a whole, a trend of $-2.41 \pm 0.56 \%$ decade $^{-1}$ has been observed for the annual SIE maximum, $-13.5 \pm 2.93 \%$ decade $^{-1}$ for 

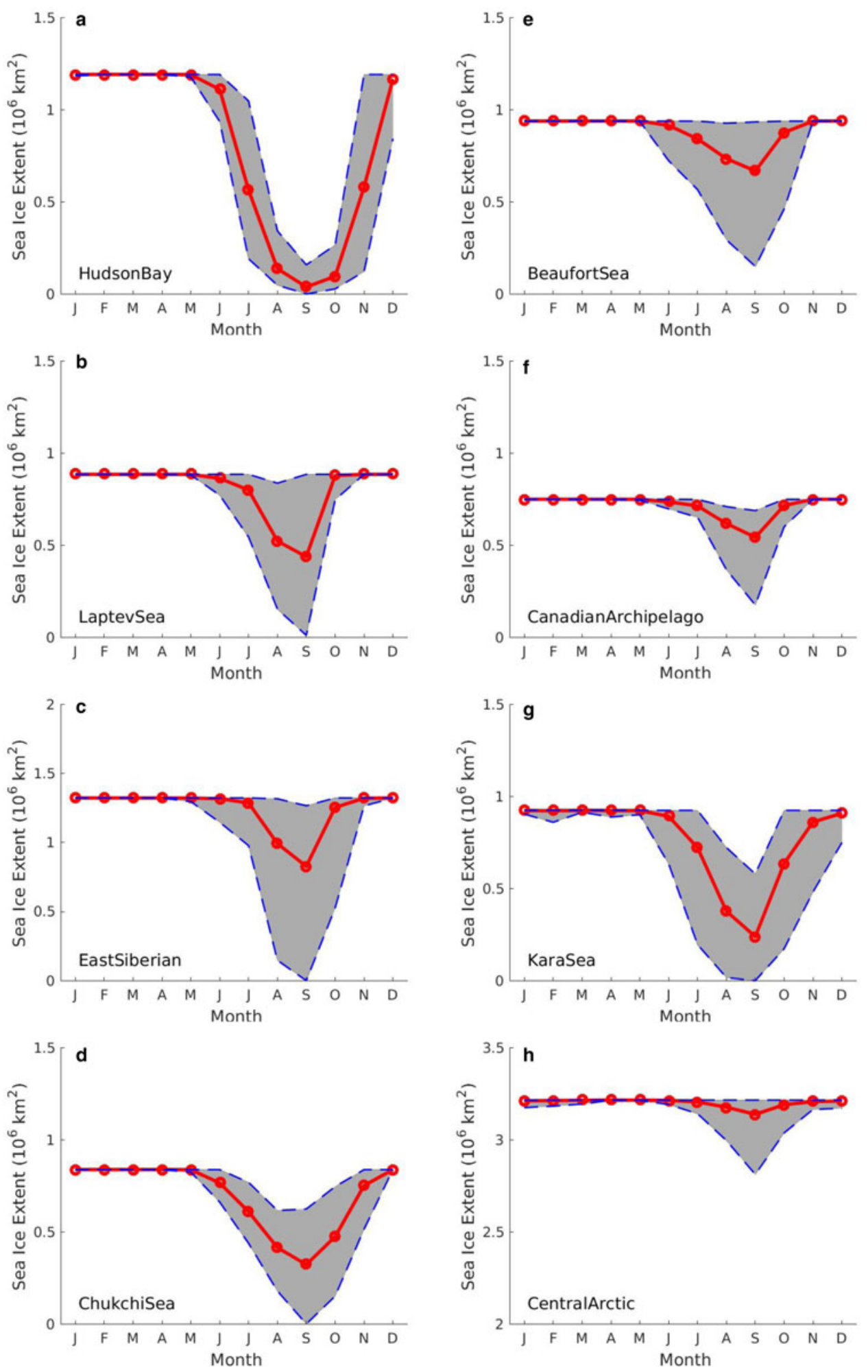

Fig. 4. Same as Fig. 3 except for type III and for the regions of (a) Hudson Bay, (b) Laptev Sea, (c) East Siberian, (d) Chukchi Sea, (e) Beaufort Sea, (f) Canadian Archipelago, (g) Kara Sea and (h) Central Arctic.

the annual SIE minimum and $5.84 \pm 2.4 \%$ decade $^{-1}$ for the difference between the two (annual SIE maximum-minimum) (Fig. 6a). The reduction in the annual SIE maximum in recent years has helped establish the statistical significance of the downward trend in the annual Arctic SIE maximum.

The annual SIE maximum represents the sea-ice reservoir, which 'replenishes' through the autumn and winter and 'depletes' through the spring and summer. A non-zero annual SIE minimum value implies the existence of multiyear ice. The difference between the annual SIE maximum and minimum is the annual spread of SIE and generally is indicative of the annual ice melt amount, though some ice is lost annually through advection out of the Arctic via Fram Strait and the channels of the Canadian Archipelago. Although there are downward trends for both the maximum and minimum SIE in the Arctic, the long-term decrease of the annual SIE minimum has outpaced that of 


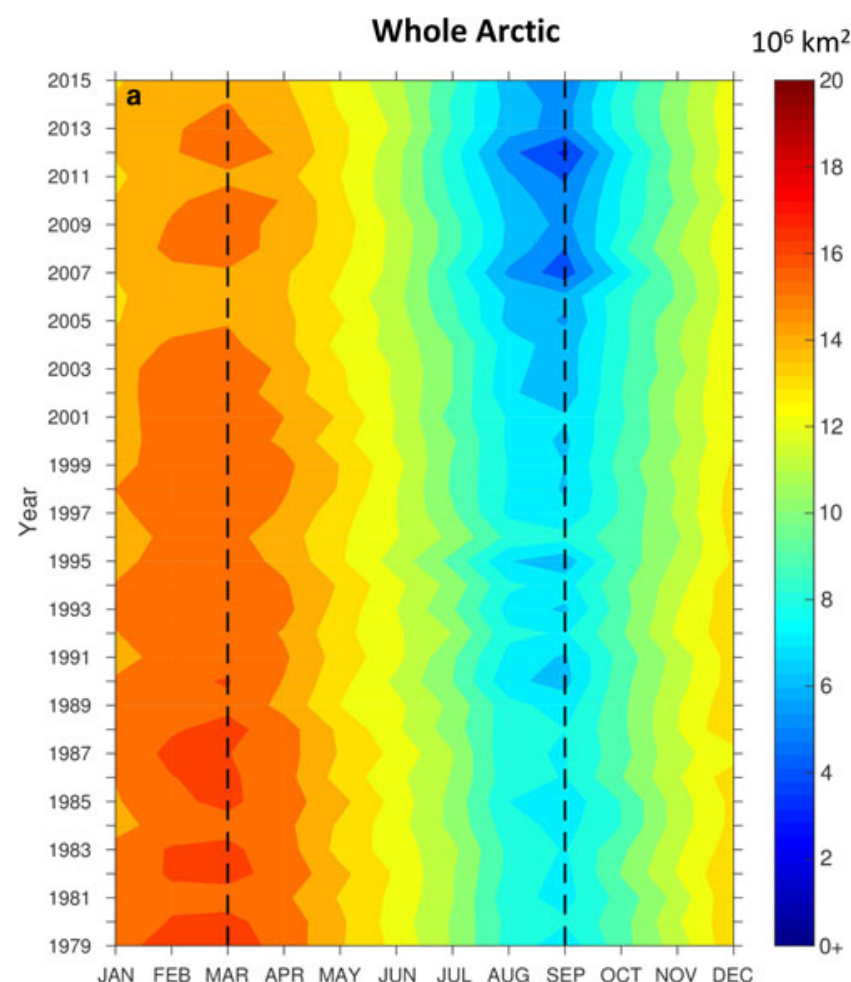

Bering Sea

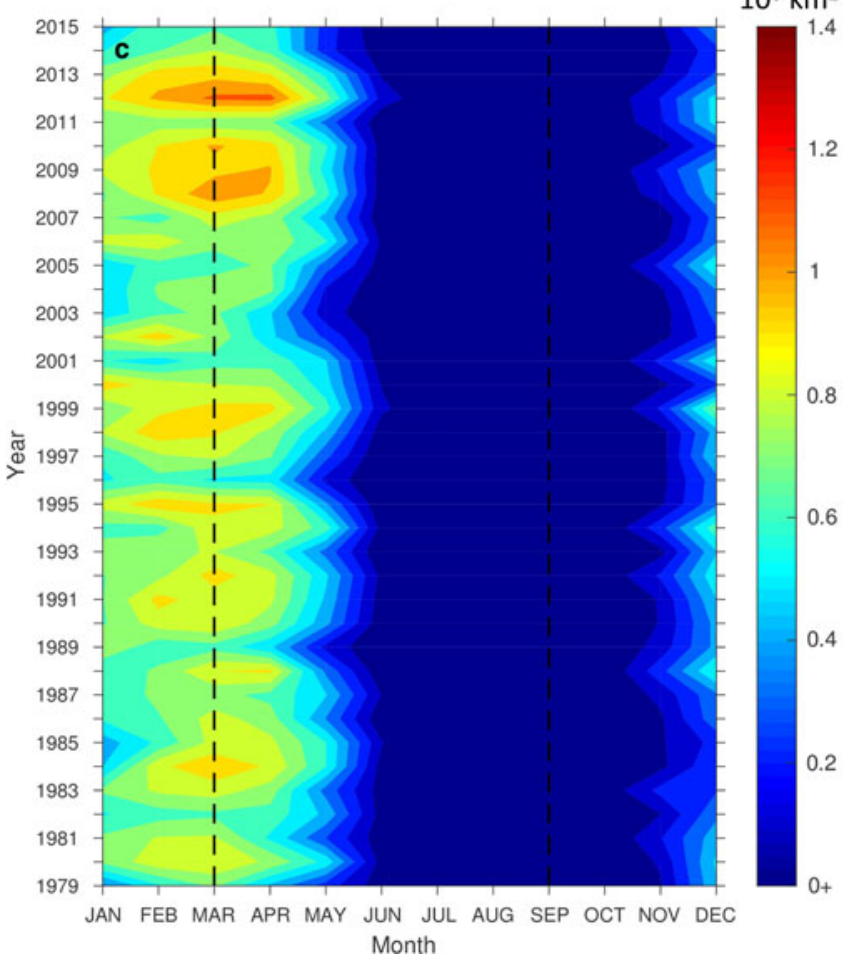

Greenland Sea $10^{6} \mathrm{~km}^{2}$

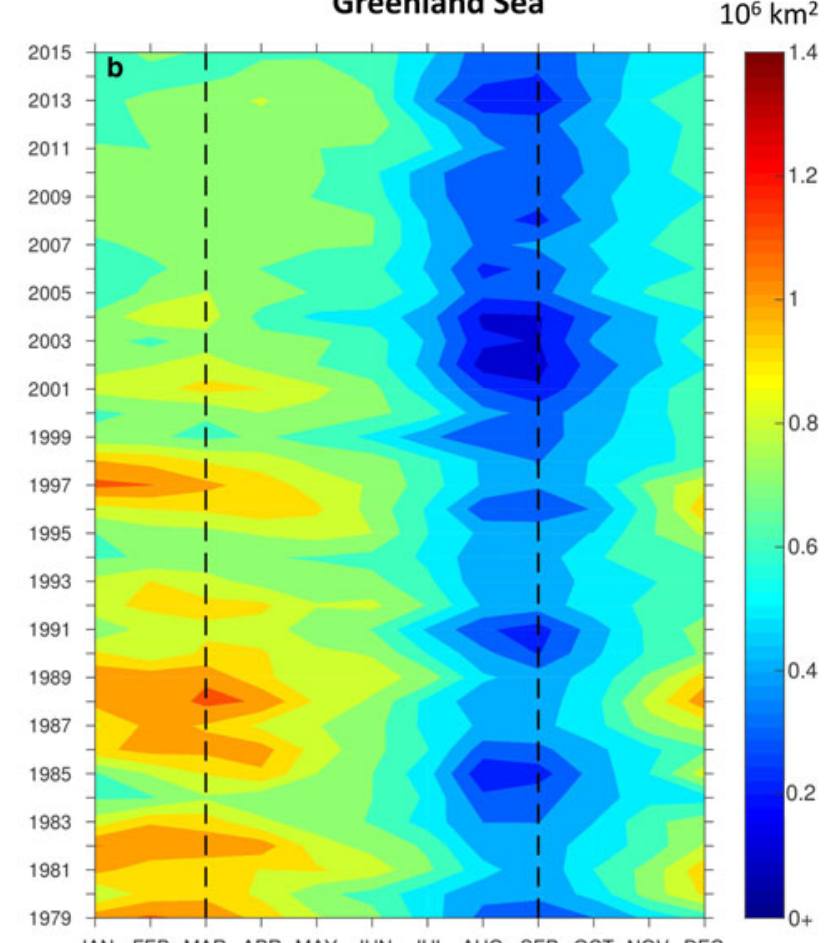

JAN FEB MAR APR MAY JUN JUL AUG SEP OCT NOV DEC

Chukchi Sea

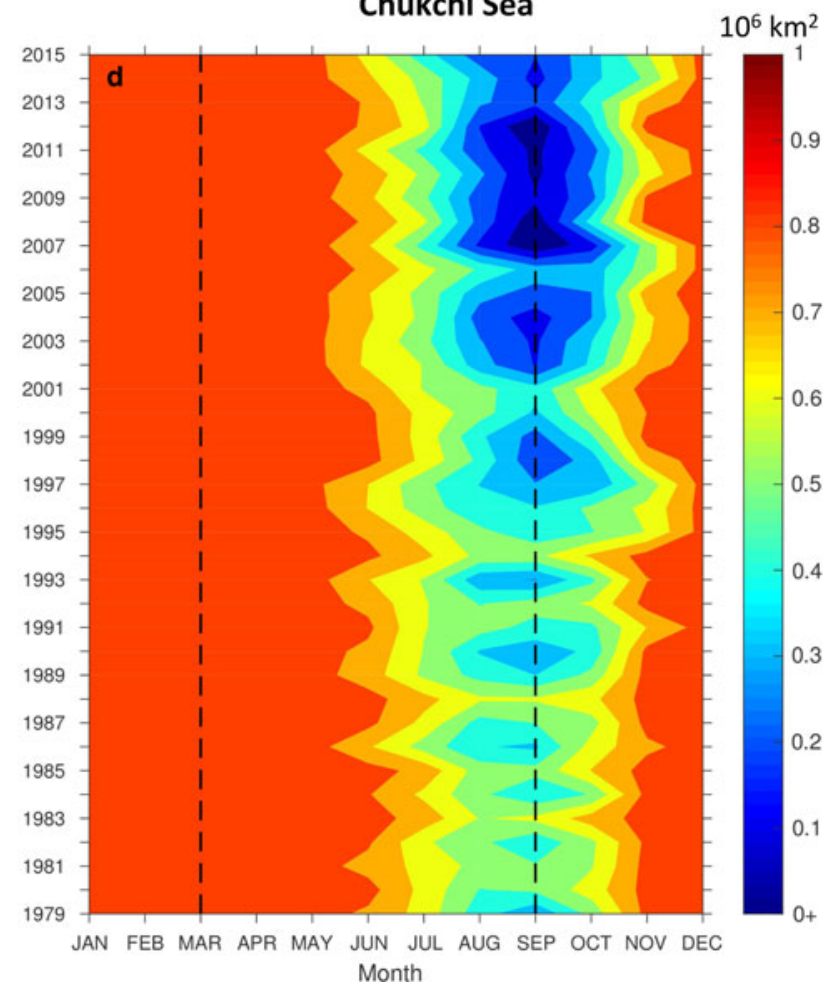

Fig. 5. Temporal distributions of monthly SIE $\left(10^{6} \mathrm{~km}^{2}\right)$ for the period of 1979-2015 for the region of (a) whole Arctic, (b) Greenland Sea, (c) Bering Sea and (d) Chukchi Sea, respectively. The value 0+ in the color scale denotes the state when there is no data cell in the region with SIC value $>15 \%$. Note that the color scale varies in the different plots.

annual SIE maximum. This suggests a reduction in multi-year ice coverage, as pointed by Polyakov and others (2017), assuming the annual sea-ice lose due to advection remains at the same level. All three decadal trends are significant at the $99 \%$ confidence level.

The majority of annual maximum and minimum values in the Arctic are within one SD from its linear regression, which is represented by the thick-green dashed line in Fig. 6a.
However, there are exceptions, such as the record high annual Arctic SIE minimum in 1996 and the record low annual Arctic SIE minimums in 2007 and 2012.

The Greenland Sea has shown similar rates of long-term changes for both annual SIE maximum and minimum as well as the spread, all significant at the $95 \%$ confidence level (Fig. 6b). The Bering Sea shows a long-term increase rate for the annual SIE maximum, but the trend is not 

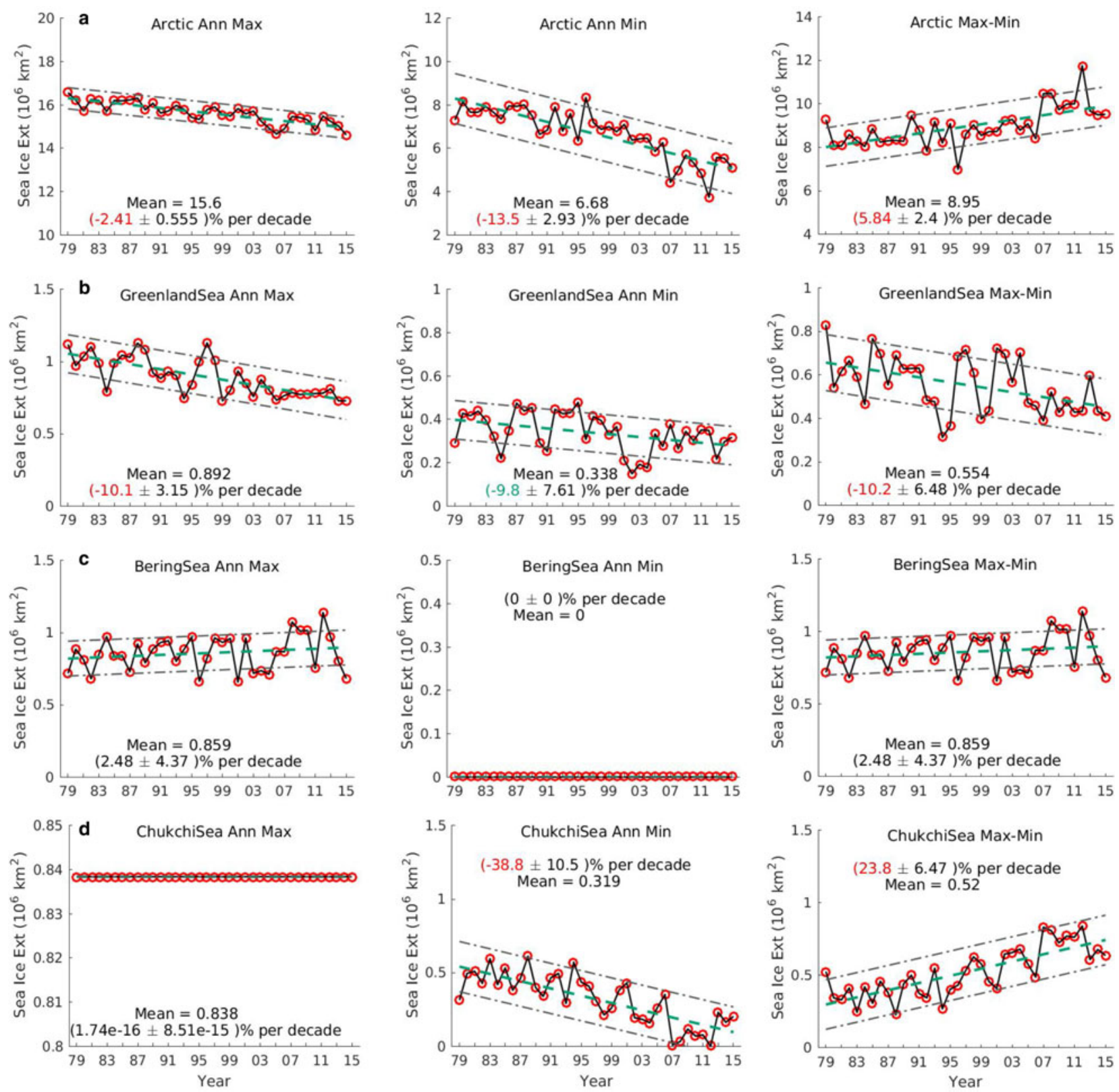

Fig. 6. Time series of sea-ice extent $\left(10^{6} \mathrm{~km}^{2}\right.$, red circles with solid black line), its linear regression trend lines (thick green dashed lines) for the annual maximum (left panels), minimum (middle panels) and the difference between the two (right panels) for (a) whole Arctic, (b) Greenland Sea, (c) Bering Sea and (d) Chukchi Sea. The dash-dotted lines are one SD of each time series. The decadal trends in percentage relevant to the regional mean in red/green are significant at the 99\%/95\% confidence level using Student's $t$-test.

significant at the 95\% confidence level (Fig. 6c). On the other hand, the Chukchi Sea shows a strong downward trend of $-38.8 \%$ for the annual SIE minimum, which is significant at the 99\% confidence level (Fig. 6d). With the persistent winter freeze, this strong downward trend results in a significant $23.8 \%$ decade $^{-1}$ upward trend in the seasonal ice loss.

Maps of intensity color-coded decadal trends in percentage of all 15 regions are shown in Fig. 7. (The trends in $10^{6}$ $\mathrm{km}^{2}$ decade ${ }^{-1}$ and their margins of error at the $95 \%$ confidence level are captured in Table 1 - the trends that are significant at the $95 \%$ confidence level are in bold.) The winter maximum ice coverage reduction in percentage is most profound in the Barents and Greenland Seas, followed by the Gulf of St. Lawrence and the Seas of Okhotsk and Japan (Fig. 7a). The map clearly shows the enhanced long-term reduction in summer minimum ice coverage in the coastal regions (Fig. $7 b$ ). Decadal trends of more than $-20 \%$ are found in Hudson Bay; the Seas of Barents, Kara, Laptev and Chukchi; and in the East Siberian region. Therefore, the Barents Sea has experienced significant ice reduction percentage wise in both annual SIE maximum and minimum.

\section{SUMMARY}

A consistent, intercalibrated, well-documented, long-term time series of the sea-ice data from remote-sensing measurements have been used to examine temporal and regional variability of Arctic sea-ice coverage.

Three types of SIE annual cycle are identified, with type II being the most vulnerable to further summer warming as summer ice-free conditions allow for more solar insolation. Continued summer sea-ice loss could potentially result in the transition of type I regions to type II. 
1979-2015 SIE Trend (\%/Decade): Ann Max

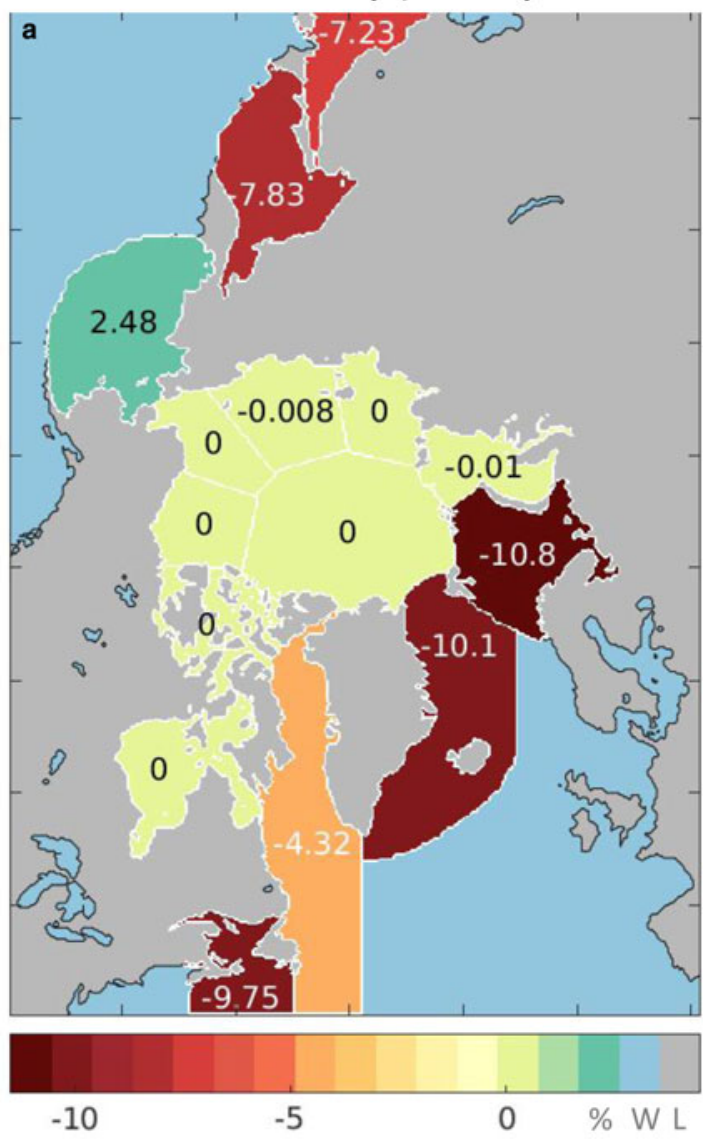

1979-2015 SIE Trend (\%/Decade): Ann Min

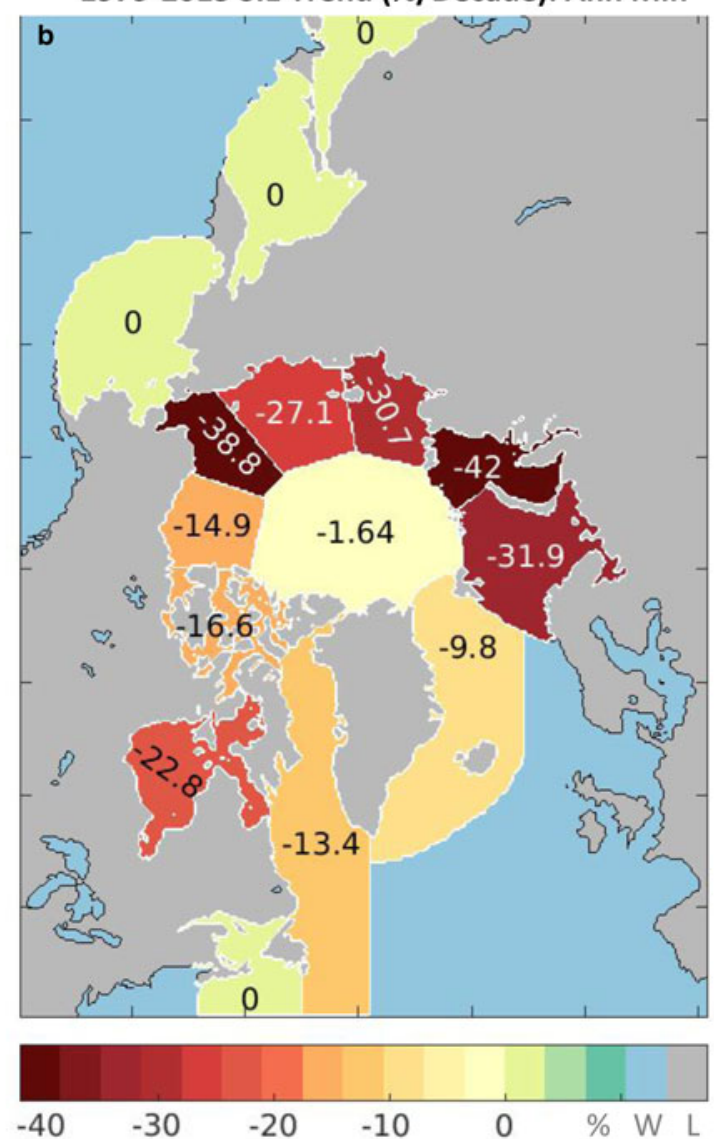

Fig. 7. Regional trends $\left(\%\right.$ decade $^{-1}$ ) for (a) annual SIE maximum and (b) annual SIE minimum for the period of 1979-2015. Landmasses are shaded gray. Other water masses are shaded in light blue.

For the annual SIE maximum, six regions tend to completely freeze-up in the winter, but all remaining regions except one experienced negative trends ranging from $\sim 0$ to $-10.8 \%$ decade $^{-1}$. The negative trends for Japan Sea, Okhotsk Sea, Gulf of St. Lawrence, Newfoundland Bay, Greenland Sea, Barents Sea and East Siberian are significant at the $95 \%$ confidence level (Table 1). Sea ice covered the whole region of the East

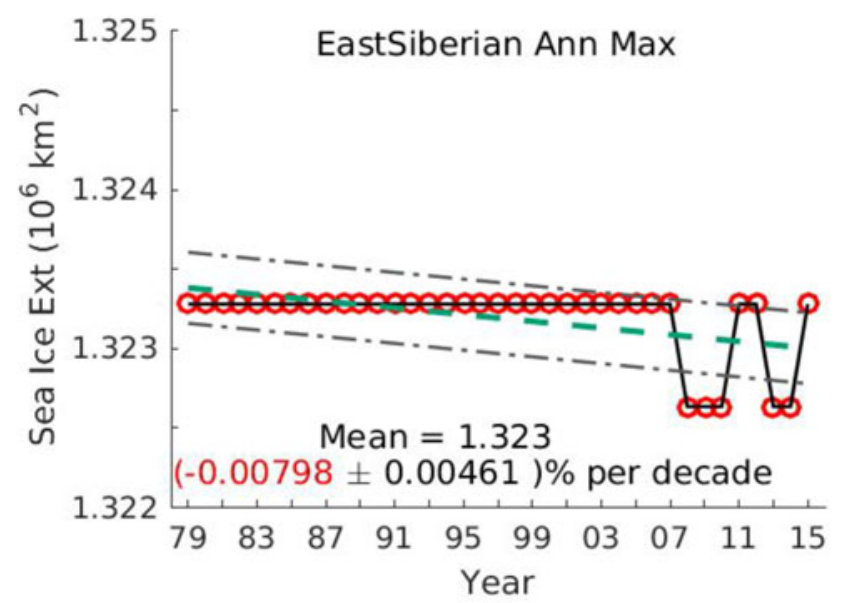

Fig. 8. Time series of the East Siberian SIE annual maximum $\left(10^{6}\right.$ $\mathrm{km}^{2}$, red circle with solid black line,) and its linear regression trend lines (thick green dashed line). The dash-dotted lines are one $\mathrm{SD}$ from the linear regression of the time series.
Siberian Sea in the first 27 years in winter since 1979. However, 5 out of the last 8 years have shown a slight erosion, which helps to establish the very small but yet statistically significant downward trend (Fig. 8). Giving the small amplitude of sea-ice loss at this stage, this trend may not be physically significant. However, if it continues, the East Siberian Sea will eventually migrate to type IIla.

At the same time, for the annual SIE minimum on the regional scale, apart from four regions that have persistent summer openings, there is a negative decadal trend of up to $-42 \%$ decade $^{-1}$. The $-42 \%$ decade $^{-1}$ trend occurred in the Kara Sea. Eight of these trends are significant at the 95\% confidence level (Greenland, Kara, Laptev, Chukchi, Beaufort, East Siberian, Canadian Archipelago and Central Arctic) (Table 1).

For the Arctic as a whole, the trend for the period of 19792015 is $-2.41 \pm 0.56 \%$ decade $^{-1}$ for the annual SIE maximum, $-13.5 \pm 2.93 \%$ decade $^{-1}$ decade for the annual SIE minimum, and $5.84 \pm 2.4 \%$ decade $^{-1}$ for the annual sea-ice melt, all significant at the $99 \%$ confidence level.

This paper presents the first SIE analysis utilizing the seaice concentration CDR produced by NSIDC and archived by NOAA's NCEI (National Centers for Environmental Information) (the dataset doi: 10.7265/N55M63M1) that meets CDR requirements on reproducibility, transparency, file format, documentation and metadata. The results shown in this paper are consistent with that in the literature.

This analysis has been carried out to establish the most up-to-date regional long-term average and variability 
characteristics of sea-ice coverage from the CDR. These SIE characteristics will be used to monitor the ice state to support climate adaptation and risk mitigation at regional scales at NCEI. It is also our hope that this paper will help standardize the way the community displays the seasonal and interannual SIE variability (Figs 3 and 5) and decadal SIE trends (Fig. 6).

\section{ACKNOWLEDGEMENT}

This work is supported by NOAA's NCEI under Cooperative Agreement NA14NES432003. Ethan Shepherd contributed to data processing. Russell Vose contributed to the design of Fig. 7. Comments and edits from Michael Palecki, Jake Crouch and Russell Vose improved the clarity and presentation of the paper. Tom Maycock and Jason Yu proof-edited the manuscript. We thank two anomalous reviewers from Annals of Glaciology for their constructed edits and suggestions, which have improved the quality and clarity of the paper. The Ferret data visualization and analysis program was used for this paper. Ferret is a product of NOAA's Pacific Marine Environmental Laboratory. (Information is available at http://ferret.pmel.noaa.gov/Ferret/). The concept of temporal distribution maps (Fig. 5) is adapted from a presentation given by Richard Hoehler.

\section{REFERENCES}

ACIA (Arctic Climate Impact Assessment) (2004) Impacts of a warming Arctic -Arctic climate impact assessment. Cambridge University Press. 140 pp. http://www.amap.no/documents/doc/ impacts-of-a-warming-arctic-2004/786

Bhatt US and 10 others (2014) Implications of Arctic sea ice decline for the Earth system. Annu. Rev. Environ. Resour., 39, 57-89 (doi: 10.1146/annurev-environ-122012-094357)

Cavalieri DJ and Parkinson CL (2012) Arctic sea ice variability and trends, 1979-2010. Cryosphere, 6, 881-889 (doi: 10.5194/tc-6881-2012)

Comiso JC and Nishio F (2008) Trends in the sea ice cover using enhanced and compatible AMSR-E, SSM/I, and SMMR data. J. Geophys. Res., 113, C02S07 (doi: 10.1029/2007JC004257)

Jeffries MO, Richter-Menge J and Overland JE, Eds. (2014) Arctic report card 2014. 75 pp. http://www.arctic.noaa.gov/reportcard

Kattsov VM and 7 others (2010) Arctic sea ice change: a grand challenge of climate science. J. Glaciol., 56, 1115-1121 (doi: 10.3189/002214311796406176)

Koldunov NV (2010) Variability of Arctic sea ice. Reports on Earth System Science. \#79/2010. 143 pp. Max Planck Institute for Meteorology. Hamburg, Germany.

Liu J, Curry JA and Hu Y (2004) Recent Arctic sea ice variability: connections to the Arctic oscillation and the ENSO. Geophys. Res. Lett., 31 (doi: 10.1029/2004GL019858)
Lynch AH, Serreze MC, Cassano EN, Crawford AD and Stroeve J (2016) Linkages between Arctic summer circulation regimes and regional sea ice anomalies. J. Geophys. Res. Atmos., 121, 7868-7880 (doi: 10.1002/2016JD025164)

Meier WN, Stroeve J and Fetterer F (2007) Whither Arctic sea ice? A clear signal of decline regionally, seasonally and extending beyond the satellite record. Ann. Glaciol., 46, 428-434 (doi: $10.3189 / 172756407782871170)$.

Meier WN and 5 others (2013) NOAA/NSIDC climate data record of passive microwave sea ice concentration, Version 2. NSIDC: National Snow and Ice Data Center under the NOAA Climate Data Record Program, Boulder, Colorado, USA. (doi: 10.7265/ N55M63M1). Updated 2016

Meier WN, Peng G, Scott DJ and Savoie M (2014) Verification of a new passive microwave sea ice concentration climate data record. Polar Res., 33, (doi: 10.3402/polar.v33.21004)

Parkinson CL (2014) Global sea ice coverage from satellite data: annual cycle and 35-yr trends. J. Climatol., 27, 9377-9382 (doi: 10.1175/JCLI-D-14-00605.1)

Parkinson CL, Cavalieri DJ, Gloersen P, Zwally HJ and Comiso JC (1999) Arctic sea ice extents, areas, and trends, 1978-1996. J. Geophys. Res., 104(C9), 20,837-20,856

Peng G, Meier WN, Scott DJ and Savoie M (2013) A long-term and reproducible passive microwave sea ice concentration data record for climate studies and monitoring. Earth-Syst. Sci. Data, 5, 311-318 (doi: 10.5194/essd-5-311-2013)

Polyakov JV, Walsh JE and Kwok R (2012) Recent changes of Arctic multiyear sea ice coverage and the likely causes. Am. Meteor Soc., 93, (doi: 10.1175/BAMS-D-11-00070.1)

Polyakov JV and 15 others (2017) Greater role for Atlantic inflows on sea-ice loss in the Eurasian basin of the Arctic ocean. Science, eaai8204 (doi: 10.1126/science.aai8204)

Semenov VA, Martin T, Behrens LK and Latif M (2015) Arctic sea ice area in CMIP3 and CMIP5 climate model ensembles - variability and change. Cryosphere Discuss., 9, 1077-1131 (doi: 10.5194/ tcd-9-1077-2015)

Serreze MC and Stroeve J (2015) Arctic sea ice trends, variability and implications for seasonal ice forecasting. Philos. Trans. R. Soc. A, 373 (doi: 10.1098/rsta.2014.0159)

Stroeve JC and 6 others (2012) Trends in Arctic sea ice extent from CMIP5, CMIP3 and observations. Geophys. Res. Lett., 39, L16502 (doi: 10.1029/2012GL052676)

Thompson A (2017) Arctic Sea Ice Sets Record-Low Peak for Third Year. Climate Central. Published: March 22, 2017. http://www. climatecentral.org/news/arctic-sea-ice-sets-record-low-peak-for3rd-year-21268

Vihma T (2014) Effects of Arctic sea ice decline on weather and climate: a review. Surv. Geophys., 35, (doi: 10.1007/s10712014-9284-0)

Yashayaev IM and Zveryaev II (2001) Climate of the seasonal cycle in the North Pacific and the North Atlantic Oceans. Int. J. Climatol., 21 (doi: 10.1002/joc.58)

Zhang JL and Rothrock DA (2003) Modeling global sea ice with a thickness and enthalpy distribution model in generalized curvilinear coordinates. Mon. Weather Rev., 131, 845-861 (doi: 10.1175/1520-0493(2003)131<0845:MGSIWA>2.0.CO;2) 